\title{
A PÓS-MODERNIDADE E A LEITURA DE OBRAS LITERÁRIAS
}

\author{
Anderson Ferreira (PUC-SP/CAPES)
}

\begin{abstract}
RESUMO
À luz das discussóes advindas da Filosofia e da Teoria Social acerca da pós-modernidade, este trabalho busca refletir, por uma perspectiva discursiva, sobre o lugar da leitura de obras literárias na contemporaneidade. Procura-se compreender como as práticas sociais como a leitura de livros são transformadas pelas condiçôes sócio-históricas do atual período histórico e pelas práticas discursivas em torno dela.
\end{abstract}

PALAVRAS-CHAVE: Pós-modernidade; leitura; obras literárias.

\section{Considerações iniciais}

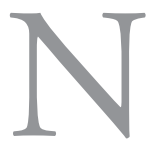

o primeiro século da era cristá, o codex ${ }^{1}$ substitui o rolo, mas não alterou a técnica da reprodução do texto, assegurada pela cópia manuscrita. A invenção da imprensa por Gutenberg não modificou as estruturas fundamentais dos livros. As revoluçóes da leitura aconteceram em condições sócio-históricas de reprodução de texto estabilizado pelo codex: "as conquistas medievais da leitura silenciosa e visual, o furor de ler que tomou conta do século das Luzes, ou, então, a partir do século XIX, o ingresso maciço na leitura de recém-chegados: os meios populares, as mulheres e, dentro ou fora da escola, as crianças”. (CHARTIER 2010, p. 9).

1 Um códice (ou codex, da palavra em latim que significa livro, bloco de madeira) é um livro manuscrito, em geral do período da Antiguidade tardia até a Idade Média. 
Contudo, as mesmas condições sócio-históricas que estabilizam práticas socioculturais produzem novas técnicas. Se a prensa de Gutenberg não modificou as estruturas elementares dos livros, permitiu, de outra forma, a produção de novas práticas de leitura. Na contemporaneidade, essas práticas de leitura se multiplicaram, e a leitura de obras literárias concorre com uma ampla e difusa materialidade discursiva disseminada pelos suportes técnicos e digitais.

No limite, parece-nos que os valores de uma sociedade moderna estão sendo descentrados. A Educação institucional reafirma, por meio de suas Orientaçóes Curriculares, seu compromisso com a história e com a cultura, ao mesmo tempo em que as exigências com o novo e com o imediato impóem-se perante a vida. Recomenda-se a obra literária com fonte cultural para uma formação autônoma e crítica, num cenário em que estas virtudes importam muito pouco. Neste particular, tenta-se redefinir o lugar da leitura da obra literária na sociedade contemporânea.

Assim, no intuito de promover uma reflexão acerca desse lugar, consideramos, na primeira parte deste trabalho, as discussóes de uma ruptura entre modernidade e pós-modernidade. $\mathrm{Na}$ segunda parte, recuperamos algumas observaçóes de Fridric Jameson acerca da pós-modernidade. Por fim, na terceira parte, refletimos acerca das noçóes de obra literária, de leitor e sobre as condiçôes sócio-históricas de produção dos livros e da leitura.

\section{Modernidade e pós-modernidade}

Uma das questóes que se coloca nos debates nas Ciências Humanas acerca da contemporaneidade é se estaríamos no cerne de uma ruptura entre dois tempos da história na cultura ocidental: a modernidade e a pós-modernidade. O termo pós-modernidade, por exemplo, é mobilizado, muitas vezes, segundo alguns pensadores, para propor discussóes não apenas sobre o fim da modernidade, mas também para situar e apreender, no atual período histórico, categorias como tempo e espaço, identidade, sujeito, família, escola, sexo, estética, ética, cultura.

Livros como $A$ identidade cultural na pós-modernidade de Stuart Hall (1992; 2011), ou ainda O mal-estar na pós-modernidade de Zygmunt Bauman (1997; 1998), por exemplo, podem ser recebidos por seus títulos como pretendentes ao exame de uma condição pós-moderna instaurada na sociedade 
contemporânea. Todavia, ao lermos estes estudos, a impressão que temos é que as fronteiras entre modernidade e pós-modernidade ainda estão sendo construídas. A noção de pós-modernidade, dessa forma, não se limitaria a configurar um signo de pertencimento ou não pertencimento. Um problema, então, é tomar aquelas categorias (tempo, espaço, sujeito ...) como externas ao atual período histórico e não como seu elemento constituinte.

Com efeito, os termos [pós]modernidade e [pós] modernismo deixaram seus encalços nas reflexôes contemporâneas, nomeadamente no campo acadêmico. Embora, muitas vezes, estas expressões pretendam situar um período histórico, devemos atentar-nos aos seus referenciais. Para Eagleton (1996), o termo pós-modernismo diz respeito, em geral, a um modo de cultura contemporânea, enquanto o termo pós-modernidade remete a um período histórico específico. Consideremos o título do livro de Stanley J. Grenz (2008) Pós-modernismo: um guia para entender a filosofia do nosso tempo. Nele se constitui, ao mesmo tempo, a ideia de pertencimento e não pertencimento a qual é especificada em sua sinopse:

Compreenda os contextos éticos, cultural e intelectual de nossos dias ao ler essa obra. Por que a mensagem do pastor, táo bem preparada, não consegue chamar a atenção de sua comunidade? Por que os cristãos mais jovens, quando entram nas universidades, perdem o interesse pelas atividades da igreja? Essas e muitas outras questóes preocupam os pastores e líderes que querem dar relevância à proclamação do evangelho em tempos pós-modernos. Muitos deles não conseguem compreender o pós-modernismo e por isso têm dificuldade em criar estratégias para falar de Deus nos dias de hoje. Foi para ajudar esses pastores e líderes que Stanley J. Grenz escreveu este livro. Nele você encontrará um estudo que o ajudará a entender as razóes que levaram ao esgotamento das promessas e filosofias da modernidade e ao surgimento dessa nova maneira de ver o mundo.

A concepção de pós-modernismo aí parece abranger muito mais que um modo de cultura contemporâneo. Mesmo que o livro tenha sido destinado a um público restrito - pastores e líderes de igrejas - seu comprometimento é 
abrangente, pois promete ajudar a "compreender os contextos éticos, cultural e intelectual de nossos dias" e fazer entender "as razóes que levaram ao esgotamento das promessas e filosofias da modernidade e ao surgimento dessa nova maneira de ver o mundo".

Neste sentido, estaríamos fadados a começar tudo do zero, já que fora imposta uma "nova maneira de ver o mundo"? Estaríamos, enfim, num lugar de uma nova origem? Onde as velhas lideranças perdem cada vez mais a palavra, onde a proclamação do evangelho seria irrelevante, posto que o discurso, "a fala tão bem preparada", não penetra nas comunidades que, aparentemente, estariam surdas, onde igrejas e universidades são instâncias interincompreensíveis? Para usar o termo de Maingueneau (2008). Em última instância, estaríamos em um lugar onde falar de Deus em 'tempos pós-modernos' consiste em pôr de lado a fé pela fé e mobilizar estratégias de toda ordem para atingir o Outro? Afinal, não seria ingênuo acreditar que estes fenômenos são específicos do atual período histórico e que poderíamos compreendê-lo apenas por meio de uma síntese 'acadêmica'?

$\mathrm{Na}$ verdade, termos como pós-modernismo e pós-modernidade carregam múltiplos sentidos, mas quase sempre são postos sob um signo de ruptura. $\mathrm{Na}$ história, sempre houve, em algum momento de uma dada sociedade, algum desapego ao discurso de liderança. Mas, no atual período histórico, o desprendimento parece ser constitutivo da identidade e as relaçóes entre os indivíduos ocorrem, no limite, como inter-relaçôes efêmeras. Ou seja, num cenário em constante movimento, onde os valores não são fixos, onde empregos e profissóes desaparecem sem deixar notícias, onde tudo é imediato e descartável, inclusive os sentimentos, as identidades são fragmentadas, ou melhor, "podem ser adotadas e descartadas como uma troca de roupa" (BAUMAN, 1998, p. 113).

Dessa maneira, como num jogo curto, a vida se inicia a cada lance, náo se fixa, movimenta-se para o outro lado e daquele para outro e assim por diante, pois as regras do jogo mudam, mesmo durante o jogo: o efêmero, por si só, se esvai. Daí não se comprometer, tampouco se planejar a longo prazo ou se fixar. As práticas socioculturais mais "contemplativas" como uma ida ao museu ou a leitura de um livro parecem estafantes. $\mathrm{O}$ modo de apreensão da cultura de uma modernidade pesada custa a se sustentar numa modernidade líquida, como diria Bauman (2000). A noção 
de crise na leitura aparece entre essa passagem, surge no momento de uma ruptura, move uma prática sociocultural secular, sem revisóes para a contemporaneidade.

Por isso, talvez, Bauman $(1998 ; 2000)$ recue na ideia de um "tempo pós-moderno" e procura defender a passagem de uma modernidade pesada e sólida para uma modernidade leve e líquida. Esse deslocamento pode ser entendido como uma cautela sobre a ideia de que estaríamos em um "novo tempo", como sugere a tradição norte-americana e como postula a sinopse do livro de Stanley J. Grenz. De fato, a noção de pós-modernidade tematiza a fragmentação como forma de vida positivada em detrimento a um referencial da razão. Em última instância, tal noção recusa a ideia de uma totalidade e da razão como sustentáculo da produção de sentido.

Em As origens da pós-modernidade, o historiador britânico Perry Anderson (1999) procura descrever, como sugere o título, as origens da concepção de pós-modernidade. $\mathrm{O}$ autor visa a examinar, de forma mais precisa, suas diversas fontes nos respectivos cenários espacial, político e intelectual, com maior atenção para a sequência cronológica e para os enfoques locais. De outra forma, Anderson procura aventar, de modo mais empírico, as condiçóes sócio-históricas e culturais que podem ter produzido o pós-moderno, segundo ele, não como ideia, mas como fenômeno.

Conforme Anderson (1999), a concepção de pós-modernismo apareceu pela primeira vez no mundo hispânico, na década de 1930, uma geração antes do seu surgimento na Inglaterra e nos EUA. Foi Frederic Onís quem lançou o termo para descrever um refluxo conservador dentro do próprio modernismo. Apenas vinte anos depois, o termo surgiu no mundo anglófono como categoria de época e não de estética.

Desta forma, nos Estados Unidos, no final dos anos 1950, o termo reaparece com uma nuance negativa pela apropriação de Charles Whight Mills (1916-1962) e Irving Howe (1920-1993), sociólogo e crítico literário, respectivamente. Em seguida, Harry Levin (1912-1994), na opinião de Anderson, aprofunda a ideia de pós-moderno, tendo como referencial a literatura, que havia "renunciado aos rígidos parâmetros intelectuais do modernismo em prol de uma relaxada meia síntese - sinal de uma nova cumplicidade entre o artista e o burguês numa suspeita encruzilhada de cultura e comércio" (LEVIN, 1986 apud ANDERSON, 1999, p. 19). 
Em 1960, Leslie A. Fiedler (1917-2003) se apropria da noção de literatura pós-moderna, para abrigar a produção cultural de jovens da América do Norte. Para Fiedler, "essa literatura produziria um cruzamento de classes e uma mistura de gêneros" (ANDERSON, 1999, p. 20). Barrento (2001) acrescenta que Fiedler teria usado o termo pós-modernidade, a fim de poder justificar e nomear o fenômeno emergente da arte pop. Desta forma, o crítico literário norte-americano postulou a necessidade de estreitar a fronteira que delimitava essa nova arte da primeira metade do século, visando, assim, a ultrapassar o limiar entre novos/velhos territórios cujos temas reaproximavam arte e vida.

Mas, neste cenário, o termo pós-moderno estava sempre imbricado ao termo moderno. Como se, para situar um depois - pós, fosse sempre preciso referir-se a um antes - moderno. Logo, "o moderno - estético ou histórico - é sempre, em princípio, o que se deve chamar um presente absoluto, ele cria uma dificuldade peculiar para a definição de qualquer período posterior" (ANDERSON, 1999, p. 20). Segundo este autor, embora o uso tenha sido constante tempos atrás, um desenvolvimento teórico do termo pós-moderno, apenas foi efetivado a partir de 1970, como veremos.

Assim, a noção de pós-modernidade não apenas promoveu discussóes na literatura, na pintura, na música, na arquitetura, nas ciências e na filosofia, mas mobilizou consideraçóes acerca de sua própria legitimidade como categoria de periodização. A supra referida sinopse do livro de Stanley J. Grenz anuncia que o leitor entenderá "as razóes que levaram ao esgotamento das promessas e filosofias da modernidade e ao surgimento dessa nova maneira de ver o mundo", ao mesmo tempo em que compreenderá "os contextos éticos, cultural e intelectual de nossos dias". Mas essa "nova maneira de ver o mundo" afetaria, substancialmente, as práticas socioculturais marcadas pela tradição? Em última instância, uma nova maneira de ver o mundo implicaria um novo modo de apreensão de seus objetos culturais?

\section{Pós-modernidade}

As questóes colocadas na seção anterior, de certo modo, tiveram lugar nas reflexôes de Fredric Jameson (1934) que propôs uma intervenção mais 
efetiva sobre a noção de pós-moderno, em especial, assinaladas, a partir de sua conferência proferida no Museu Whitney de Artes Contemporâneas em 1982, a qual teve ampliados e desenvolvidos seus principais tópicos no ensaio Postmodernism or the Cultural Logic Late Capitalism publicado na New Left Review, número 146, em 1984. Anderson (1999) destaca cinco intervençóes decisivas nos estudos de Jameson.

A primeira diz respeito ao título da conferência. A segunda refere-se à problemática da subjetividade. A terceira concerne à cultura. A quarta refere-se às bases sociais e ao padrão geopolítico do pós-modernismo. A última considera a proposta de uma saída para certo maniqueísmo de valoração sobre o pós-moderno. "A partir de opiniōes políticas distintas, o crítico poderia ou lamentar o advento do pós-moderno como corrupção do moderno ou celebrá-lo como uma emancipação" (ANDERSON, 1999, p. 77). É necessário observar que estas intervençóes estáo, hierarquicamente, intrincadas. Dito isto, daremos ênfase aqui às três primeiras.

Em sua primeira intervenção, a respeito do título da conferência Pósmodernidade e sociedade do consumo, Jameson (1985) não apenas propóe uma superação das discussóes em torno da ruptura estética ou mudança epistemológica, mas procura ancorar o pós-modernismo "em alteraçóes objetivas de ordem econômica do próprio capital” (ANDERSON, 1999, p. 66). Neste quadro, a pós-modernidade é focalizada como um referencial cultural de um novo período na história do modo de produção dominante.

A expressão "sociedade do consumo" presente no título da conferência anunciou o que seria desenvolvido mais verticalmente no ensaio de 1984. Em New Left Review, Jameson ressaltou a expansão da eletrônica moderna a qual relacionava lucro e inovação, também a hegemonia das multinacionais na produção global e sua exploração da força de trabalho em países mais pobres; a hipertrofia da especulação internacional e, finalmente, o monopólio de algumas empresas das técnicas de informação e comunicação. Como argumenta Anderson (1999),

Esses fenômenos tiveram profundas consequências em cada dimensão da vida nos países industriais avançados - nos ciclos de negócio, nos padróes de emprego, nas relaçóes de classe, nos destinos regionais, nos interesses políticos. Numa perspectiva 
mais ampla, porém, a mudança mais fundamental de todas está no novo horizonte existencial dessas sociedades. A modernização estava agora quase concluída, apagando os últimos vestígios não apenas de formas sociais pré-capitalistas como de todo território natural intacto, de espaço ou experiência, que as sustentara ou sobrevivera a elas.

Deste modo, a sensação de entrar em um "novo mundo" ou em uma nova era é compreensível em trabalhos que pretendem alocar categorias como família e sexo, por exemplo, em uma sociedade em que estas e outras categorias de uma sociedade burguesa se deslocaram juntamente com a noção de identidade. Na visão de Anderson (1999), neste universo, a cultura se expandiu, tornando-se produto de consumo, ao mesmo tempo em que o modernismo retirava seu desígnio e forças da "persistência do que ainda não era moderno, do legado de um passado ainda pré-industrial, o pós-modernismo é superação dessa distância, a saturação de cada polo do mundo com o soro do capital" (ANDERSON, 1999, p. 67). Desta maneira, no que tange à problemática da subjetividade, tais condições sócio-históricas têm importância significativa.

Em sua segunda intervenção, na Conferência de 1982, Jameson póe em discussão, a partir do comentário sobre a morte do sujeito - “ou em expressão mais tradicional, o fim do individualismo como tal" (JAMESON, 1985, p. 19) -, o tema da subjetividade, aprofundando-o em estudos ulteriores. Para este autor, o universo do modernismo liga-se à concepção de um caráter individual, ou seja, a estética da modernidade vincula-se, de modo híbrido, à ideia de um eu singular, cuja identidade particularizada apresentava uma visão idiossincrática do mundo. Ao contrário, no pós-modernismo, este sujeito individual, dotado de uma visão particular do mundo, fora liquidado, ou, numa posição mais radical, ele realmente nunca existiu. $\mathrm{Na}$ opinião de Anderson (1999), entre as marcas dessa nova subjetividade estaria a perda da percepção de história, seja com o passado, seja com o futuro; a vida, então, passa a ser, sempre, o agora.

Jameson (1985) desenvolve dois traços, segundo ele, significativos da pós-modernidade: o pastiche e a esquizofrenia. Tal como a paródia, a noção de pastiche pode ser entendida como a imitação de um estilo singular ou único, "a utilização de uma máscara estilística, uma fala em língua morta: mas a sua 
prática desse mimetismo é neutra, sem as motivaçóes ocultas da paródia, sem o impulso satírico, sem a graça, sem aquele sentimento ainda latente de que existe uma norma” (JAMESON, 1984, p. 18).

Assim, a ideia de sujeito sem subjetividade e de cultura performática pode ser observada no campo das descriçôes sociológicas e estéticas. O pós-moderno situa uma cultura do radical em extensão que, diferentemente da cultura moderna, "não é crítica nem rigorista, é performativa e transgênica, híbrida e permeável, quase já só tem corpo e sexo. O resultado: um enorme tédio, porque não se pode ir mais longe do que o corpo, e porque a banalização do gesto pretensamente extremo nos deixa cada vez mais indiferentes" (BARRENTO, 2001, p. n/p). Eis que na sociedade contemporânea o mimetismo pós-moderno imita, sem humor, aquilo que é por si só uma imitação sem graça.

A noção de esquizofrenia, por seu turno, dialoga, nos termos de Jameson (1985), com a teoria desenvolvida na obra do psicanalista Jacques Lacan (1901-1981). Lacan nos oferece uma versão linguística do complexo de Édipo, segundo a qual a rivalidade edipiana é interpretada em termos que o psicanalista francês chama de Nome-do-Pai, ou seja, a autoridade paterna se converte em função linguística. Em sua leitura, Jameson (1985) procura retirar a ideia de que "a psicose e, mais particularmente, a esquizofrenia se formam a partir da deficiência infantil em aceder plenamente ao domínio da fala e da linguagem" (JAMESON, 1985, p. 22).

Jameson (1985) argumenta que, ao se referir à linguagem, o modelo lacaniano se funda em um estruturalismo ortodoxo, segundo o qual a noção de signo linguístico é composta por três componentes, quais sejam: um significante, um significado e um referente. Os dois primeiros comporiam o signo em sua materialidade (palavra, som, texto) e seu sentido. O referente, por sua vez, é o objeto do mundo real ao qual o signo remete.

Desse modo, se nos resta o próprio signo (significante e significado) e, de fato, não traduzimos as palavras termo a termo e sim por intermédio da inter-relação entre as palavras e seus significantes, Jameson ressalta, em sua leitura de Lacan, que o que lemos são os efeitos de sentido, ou seja, o sentido seria "o efeito produzido pelo inter-relacionamento das materialidades significantes" (JAMESON, 1985, p. 22). Deste modo, a esquizofrenia seria uma perturbação do convívio entre os significantes. Como, para Lacan, a experiência da temporalidade, a identidade individual e a existência no tempo são, também, 
um efeito da linguagem - e esta possui passado e futuro -, temos a sensação de que vivemos experiências objetivas no tempo.

Apesar disso, Jameson argumenta que o esquizofrênico não percebe desta forma a combinação da linguagem, tampouco atinge uma experiência de continuidade temporal, "estando condenado, portanto, a viver em um presente perpétuo, com o qual os diversos momentos de seu passado apresentam pouca conexão e no qual não se vislumbra nenhum futuro no horizonte" (JAMESON, 1985 , p.22). Esta interpretação não apenas articula a subjetividade com a temporalidade como também mobiliza uma noção de identidade no universo pós-moderno. Em certa medida, o esquizofrênico poderia ser considerado despossuído de uma identidade pessoal, porque sua relação com o tempo é a-histórica.

Numa terceira intervenção, no que concerne ao exame do pós-moderno no âmbito da cultura, Anderson (1999) argumenta que a obra de Jameson propôs uma inovação. Enquanto as investigações, até aquele momento, davam conta de focalizar o pós-moderno por campos, como Levin e Fildler com a literatura, Hassan com pintura e a música, Jencks com a arquitetura, Lyotard com a ciência e Habermas com a filosofia -, Jameson expande a crítica do pós-moderno por todo o conjunto das artes e, em especial, as práticas discursivas em relação a elas. "O resultado é um painel da época incomparavelmente mais rico e abrangente do que qualquer outro registro dessa cultura" (ANDERSON, 1999, p. 69)

Não obstante, destacamos uma reflexão de Jameson (1985) que nos remete a duas noçóes centrais nas discussóes até o momento: a noção de pertencimento e não pertencimento e a noção de periodização de um tempo histórico, concepções que se desdobram em categorias como sujeito, identidade, tempo e espaço, por exemplo. Caso consideremos que, de fato, vivemos em um novo período, o que significaria, de modo objetivo, pertencermos ou não à pós-modernidade? Para Jameson (1985), a primeira objeção que pode ser feita sobre a questão é a alegação de que as categorias levantadas em relação ao pós-modernismo também podem ser verificadas no modernismo canônico, isto é, não são traços novos pelos quais poderíamos justificar o conceito de pós-modernidade.

Esta questão coloca em evidência os modos pelos quais os autores postulam a ideia de ruptura entre modernidade e pós-modernidade. Ou mesmo, a defesa de uma continuidade da modernidade que resultaria em uma alta 
modernidade ou modernidade avançada (GIDDENS, 1991), ou em uma modernidade líquida (BAUMAN, 2000) ou, ainda, em uma hipermodernidade (LIPOVETSKY, 2004). Como podemos observar, as categorias de identificação de uma ruptura ou de uma [des] continuidade, embora por abordagens diferentes, se encontram quase sempre no cerne daquilo que chamamos, de modo genérico, de cultura.

Para Jameson (1985), as rupturas entre períodos observadas na história não revelam mudanças profundas nos conteúdos, mas remodelamentos ou reconfiguraçóes de elementos outrora existentes. "Traços que, em período ou sistema anterior, eram secundários se tornam agora dominantes, e traços que eram dominantes se tornam, por sua vez, secundários" (JAMESON, 1985, p. 25). De outro modo, alguns traços náo se alteram de modo profundo nas sociedades, como a desigualdade social. Talvez, em uma análise em termos de luta de classes, esta situação dificulte pensar na ideia de ruptura que, muitas vezes, não é assumida por alguns estudiosos (SANTOS, 2000, FREIRE, 1987; 1989), cuja reflexão se constrói em termos de transição.

$\mathrm{Na}$ concepção de Jameson (1985), no entanto, o que justificaria a determinação de um novo período histórico diz respeito a uma mudança de foco dos elementos presentes nos períodos. Em outras palavras, o que antes era um elemento marginal, hoje é central na produção de cultura, e, acrescentemos, nas práticas socioculturais. $\mathrm{O}$ autor sugere que existiria uma condição sócio-histórica de ruptura, haveria um desejo implícito de romper com o estabelecido e, de outro modo, a arte e os objetos culturais que estavam postos se encontrariam surdos para o diálogo com o novo, precisando de um impulso subversivo.

Contudo, na contemporaneidade, este impulso torna-se, de certo modo, manso pela possibilidade de consumo de sua arte, bem como pela canonização da arte operada no âmbito das universidades. No caso da literatura, como aponta o crítico literário brasileiro Antônio Cândido (2015), a crítica universitária, no Brasil, não se arrisca a investigar autores não canônicos. Dessa forma, não se compromete a produzir juízo sobre autores e obras literárias, uma vez que este juízo já está pronto. É o que Jameson chama de esvaziamento do potencial subversivo da obra.

Dessa maneira, assumindo, definitivamente, a ideia de ruptura, o autor procura descrevê-la em termos de períodos. Assim, diz Jameson (1985, p. 26), 
Como venho sugerindo, marxistas e não marxistas confluíram para um sentimento comum de que a certa altura, após a II Guerra Mundial, uma nova espécie de sociedade começava a se formar (variadamente descrita como sociedade pós-industrial, capitalismo multinacional, sociedade de consumo, sociedade das mídias e assim por diante). Novos tipos de consumo, obsolescência programada, um ritmo ainda mais rápido de mudanças na moda e no styling, a penetração da propaganda, da televisão e dos meios de comunicação em grau até agora sem precedentes e permeando a sociedade inteira, a substituição do velho conflito cidade e campo, centro e província, pela terceirização e pela padronização universal, o crescimento das grandes redes de autoestradas e o advento da cultura do automóvel - são vários dos traços que pareciam demarcar uma ruptura radical com aquela sociedade antiquada de antes da guerra, na qual o modernismo era ainda uma força clandestina.

Nessa senda, o autor ancora o pós-modernismo nas transformações do capital, sem deixar de notar o deslocamento da noção de sujeito e de subjetividade, mas destaca, nessa relação, o apagamento do sentido de história o qual é fundamental no estudo de leitura. Por fim, Jameson (1985) deixa uma questão acerca do valor crítico da arte pós-moderna. Se há consenso que a modernidade agiu de modo contestatório à sociedade, em que medida a pós-modernidade proporia algo semelhante? Observamos que há uma forma pela qual a "pós-modernidade repercute e reproduz - reiterando a lógica do capitalismo da sociedade de consumo. A questão mais importante é saber se também existe uma forma de resistência a essa lógica” (JAMESON, 1985, p. 26).

De fato, o atual período histórico impóe mudanças nas práticas socioculturais, entre elas a leitura e a escrita. Nesse cenário, algumas questóes relevantes podem ser destacadas: o apagamento da noção de história, a separação do tempo e do espaço, uma nova concepção de sujeito e de identidade, a cultura como objeto de consumo, o estatuto da política e da economia, o advento das técnicas e das tecnologias. Mesmo que estes estados de coisas afetem as nossas vidas nas sociedades, são fenômenos bastante abstratos que precisamos olhar de modo mais cuidadoso. 


\section{Leitura e obra literária na pós-modernidade}

Nesse particular, nossa discussão sobre leitura de obras de literárias visa a considerar práticas discursivas em torno do campo da leitura e da literatura. A princípio, destacamos o conceito de obra literária e a concepção de leitor. Depois, conforme as condições sócio-históricas e culturais de produção, circulação e disseminação dos livros, as práticas discursivas acerca da problemática da leitura de obras literárias serão ilustradas por dois recortes, a saber: os objetivos da pesquisa Retratos da Leitura no Brasil e um enunciado acerca da vendagem do livro Toda Poesia de Paulo Leminski (2013).

Retiramos do E-Dicionário de Termos Literários (EDTL) a seguinte descrição de obra: "Palavra cuja origem remonta ao latim (opèra, ae) e que denomina qualquer produçâo de um agente ou indivíduo, no âmbito das letras, ciências ou artes, com maior ou menor relevo na área em que se insere. Assim, é o resultado de uma ação ou do trabalho de um ou mais autores." (ALVES, 2015). No que tange à literatura, segundo o verbete, a obra literária consiste de uma produção unitária, que exige a interpretação de um leitor sobre um tema, e sua intencionalidade literária revela aspectos socioculturais, políticos, econômicos, históricos etc., "podendo ainda encontrar-se ao serviço da educação, ao assumir um papel moralizador.” (ALVES, 2015).

Nesse sentido, na contemporaneidade, poderíamos considerar obra literária os romances, livros de poemas, livros de autoajuda, biografias e livros religiosos, por exemplo. Quanto à estrutura da obra literária, sua organização é estável e contém os elementos tradicionais como capa, prefácio, posfácio etc. $\mathrm{Na}$ descrição do verbete, chama-nos a atenção o fato de se destacar o conceito de obra-prima (do latim, magnum opus). Segundo Alves (2015), estas obras se evidenciam e tornam-se patrimônio comum, ao qual se dá o nome de cânone. Mas recuperemos aqui as discussóes de Jameson (1985) acerca da estética moderna vinculada a um eu singular.

A ideia de produção individual e intencionalidade literária remetem-nos a uma estética moderna acadêmica, fundamentada, entre outros aspectos, na singularização do autor e/ou da obra, desprezando, por vezes, as condiçóes sócio-históricas que possibilitaram essa produção. Todavia, na pós-modernidade, como afirma Jameson (1985), o sujeito individual é desconstruído. A obra literária, neste cenário, passaria a ter muitos colaboradores, deslocando a 
própria noção de autoria. O que explica, em parte, a seguinte complementação no verbete: "pode ser considerada obra-prima a melhor produção de um autor, a mais lida, a mais conhecida (por vezes, também a mais comercializada) ou a obra inicial de um determinado gênero" (ALVES, 2015).

A "melhor produção de um autor" pode ser apreendida ainda numa dimensão estética que deve ser legitimada por sujeitos "autorizados" para tal. No entanto, as categorias de "mais lida, mais conhecida e mais comercializada", bem como a categoria de gênero, consideram as condiçôes sócio-históricas de produção, circulação e disseminação dos textos. Mas essas categorias, por si só, não promovem uma obra ao estatuto de obra literária, porque, se assim o fizessem, tornaríamos como obras-primas, indiscriminadamente, livros como o Senhor dos Anéis, Crepúsculo, Cinquenta Tons de Cinza, Crime e Castigo, Dom Casmurro, Grandes Sertóes Veredas, Quem mexeu no meu queijo, Nada a perder ${ }^{2}$. Para tanto, existem, na sociedade, instâncias que legitimam a qualidade dessas obras, e esse critério não se dá a posteriori, ou seja, uma obra não é uma obra-prima porque foi lida, conhecida ou comercializada de modo abundante, ela já o era, por isso, trata-se de uma discussão estética.

Contudo, como observa Jameson (1985), a estética moderna liga-se a um eu singular, herança de um sujeito moderno de identidade fixa e, ao mesmo tempo, procura atuar na produção pós-moderna que desconstrói esse $e u$. Neste particular, a pós-modernidade problematiza a própria noção de estética. Como no caso do pastiche, a produção pós-moderna tende a fazer "colagens", o que desloca as noçóes de sujeito e de identidade. E por que não dizer: desloca a avaliação de uma obra que, por falta de critérios estéticos, passa a ser qualificada pelo número de cópias vendidas e, no limite, por sua fama.

Caso consideremos que o critério de vendagem é um indício razoável para se considerar uma obra literária e o critério estético já não é confiável, pois as marcas da subjetividade revelariam nos sujeitos a perda da percepçáo de história, fazendo-os viver numa espécie de esquizofrenia social, em que somente o agora é alcançável, se ponderamos esta possibilidade, temos que recorrer à categoria de sujeito-leitor, já que, num quadro de consumo abundante, é ele que dá as cartas.

2 Relação de autores dos livros citados na ordem da citação: J.R.R. Tolkien; Stephene Meyer; E.L. James; Fiodor Dostoïevski; Machado de Assis; Guimarães Rosa; Spencer Johnson; Edir Macedo. 
Tomando por base os tipos de habilidades sensoriais, perceptivas e cognitivas intrínsecas aos modos de leitura, Santaella (2011), neste particular, considera que há três tipos de leitores, a saber: o leitor contemplativo, o leitor movente e o leitor virtual.

Segundo esta autora, o leitor contemplativo se relacionaria com os objetos e signos duráveis, isto é, sua relação é mais produtiva com os livros, os quadros, as imagens expostas, tudo aquilo que poderia ser alcançado com os sentidos. Nestes, a visão se destacaria como alavanca da imaginação, no caso de ler um livro, este leitor poderia sempre revisitá-lo, reorganizá-lo, ressignificá-lo. "Sendo objetos imóveis, é o leitor que os procura, escolhe-os e delibera sobre o tempo que o desejo lhe faz dispensar a eles" (SANTAELLA, $2011 \mathrm{n} / \mathrm{p}$ ). Este é um leitor, portanto, de objetos culturais que foram transmitidos pelas geraçóes. É um leitor, conforme Santaella (2011), nascido no Renascimento e apagado no século XIX, dando espaço ao leitor movente.

O leitor movente, por sua vez, oriundo dos grandes centros urbanos, imerso nas informações veiculadas pela imprensa jornalística do século XVIII em diante, possuiria uma identidade híbrida, fragmentada. Ele estaria imerso no mundo efêmero das novidades e responderia aos estímulos de leitura de toda ordem, logo haveria a necessidade de uma reconfiguração dessas leituras. $\mathrm{O}$ rádio, o cinema e a TV, por exemplo, consistem em polos de informaçáo e entretenimento e, ao mesmo tempo, atravessam os meios de informação como os jornais e revistas.

O leitor movente começa, então, a lidar com formas, com imagens intercaladas na linguagem verbal, com enunciados subentendidos, com leituras apressadas ou passageiras. Assim, submerso a uma leitura descontínua e fluida e submetido a diversos estímulos visuais e verbais, o leitor movente substitui o leitor do livro: leitor sem urgências. Aquele "leitor de formas, volumes, massas, interações de forças, movimentos, leitor de direçôes, traços, cores, leitor de luzes que se acendem e se apagam" (SANTAELLA, 2011, n/p). Para este leitor, a noção de tempo e espaço muda, mudando a forma de apropriação do escrito, possibilitando, enfim, a produção e criação dos efeitos de sentido nas práticas de leitura.

$\mathrm{Na}$ era digital, outro leitor pôde emergir: um leitor navegador. Trata-se de um "leitor implodido, cuja subjetividade se mescla na hipersubjetividade de infinitos textos num grande caleidoscópico tridimensional, onde cada 
novo nó e nexo pode conter uma outra grande rede numa outra dimensão" (SANTAELLA, 2011, n/p). De qualquer modo, outro espaço instaura-se com o advento das tecnologias digitais. Esse ciberespaço pode ser experienciado como um lugar de formas de comunicação diferentes daquele que estamos acostumados desde a consolidação das mídias tradicionais. Também, como um espaço cujas potencialidades mais positivas podem ser exploradas "nos planos econômico, político, cultural e humano” (LÉVY, 2009, p. 9) sem, no entanto, deixarmos de produzir um olhar crítico a sua configuração.

Nessa perspectiva, o leitor, no ciberespaço, exerce um poder que, de certo modo, desestabiliza um monopólio de informação. Todos os tipos de leitores parecem estar conectados, produzindo e renovando os efeitos de sentido na prática de leitura. Por isso, não estamos certos de que cada tipo de leitor explicitado por Santaella (2011) dá lugar ao outro de modo tranquilo. Parece que não é o leitor que deixa de existir ou se rarifica, mas são as condiçóes sócio-históricas de leitura que determinam as formas de apropriação dos discursos.

Nestas condiçóes, incluem-se os meios materiais e técnicos disponíveis e os modos de produção e circulação de textos. As condiçóes sócio-históricas de leitura no século XVIII, por exemplo, eram diferentes das do século XX. Neste século, as técnicas da informação e comunicação mudaram, de modo significativo, as condições de produção, circulação, disseminação e recepção dos discursos. As condiçóes sócio-históricas e culturais de produção e recepção da pós-modernidade determinam as condições das práticas socioculturais, entre elas: a leitura. Estamos certos de que esses três tipos de leitores descritos por Santaella (2011) coexistem na pós-modernidade, aliás, podemos considerar a multiplicidade de leitores e leituras pelas noçóes de sujeito e identidade na pós-modernidade. Por isso, essas formas de leitura podem, mesmo, ser praticadas por apenas um sujeito empírico. Aquele que lê em seu computador, mas, circulando pela cidade, lê o mundo em movimento, também, num final de semana, lê quadros e esculturas num museu e livros em uma biblioteca pública, lê por horas sem querer ser interrompido.

O lugar da leitura de obras literárias parece ter perdido a centralidade com o apagamento da ideia de um leitor contemplativo. $\mathrm{Na}$ contemporaneidade, todavia, a leitura dessas obras tem seu lugar na constituição de um leitor movente ou de um leitor navegador, ambos resultantes das condiçóes sócio-históricas e culturais do atual período histórico. Contudo, no quadro 
semântico de uma crise na leitura, as práticas discursivas procuram colocar a leitura de obras literárias num lugar estável: o campo do consumo.

Para ilustrar o que dissemos até aqui, citamos, como primeiro exemplo, os objetivos da pesquisa Retratos da Leitura no Brasil; são eles: [1] "Levantar o perfil do leitor e do não leitor de livros; coletar as preferências do leitor brasileiro; identificar as barreiras para o crescimento da leitura de livros no Brasil; levantar o perfil do comprador de livros no Brasil; identificar a penetração da leitura de livros no Brasil e o acesso a livros". ${ }^{3}$

Todos estes objetivos procuram reorganizar uma logística do mercado editorial, isto é, mobilizar o consumo do livro, embora o documento também aponte para uma contribuição no âmbito das políticas públicas em educação, como observa o estudo Retratos da Leitura no Brasil em sua introdução:

É a contribuição do mercado editorial para, a partir de um amplo diagnóstico, estimular novas reflexões e decisóes em torno de possíveis novas intervençôes para melhorar os atuais indicadores sobre o comportamento leitor da população. Seus resultados ajudarão o próprio IPL bem como outras instituições públicas e do mercado editorial a orientar suas açóes. A pesquisa Retratos da Leitura no Brasil tornou-se uma referência quando se trata do comportamento leitor no país, desde seu lançamento em 2001. Seus resultados foram amplamente divulgados e orientaram estudos; projetos e a implantação de políticas públicas do livro e leitura no país.

De outra forma, no que se refere às políticas públicas em leitura, "a falta de continuidade dessas políticas e o pouco envolvimento da sociedade civil e demais atores sociais contribuíram para que o país chegasse ao século XXI com uma média de leitura por ano equivalente a 1,8 livro por habitante, segundo dados da CBL" (ODDONE \& ROSE, 2006, p. 185) Ou seja, este tipo de diagnóstico revela que a leitura de livros não tem lugar cativo nas práticas socioculturais na contemporaneidade, tal que precisa ser fomentada. Resta saber se não é a própria noção de leitura que precisa ser problematizada.

3 Consta na seção Objetivos da pesquisa. 
A revolução digital, na contemporaneidade, tende a romper o elo entre textos e objetos e entre discursos e sua materialidade. Neste particular, torna-se necessário, na visão de Chartier (2010), uma revisão absoluta das representaçôes e dos conceitos que construímos acerca do escrito e da leitura.

Como segundo exemplo, consideremos o seguinte enunciado: [2] "Paulo Leminski bate Cinquenta Tons de Cinza em lista de mais vendidos”. O livro intitulado Toda Poesia reúne a produção poética de Leminski e foi publicado pela Companhia das Letras em 2013. Esta obra esteve no topo da lista dos mais vendidos durante todo o mês de março daquele ano, passando à frente de livros como Cinquenta Tons de Cinza de E.L. James. Esse fenômeno gerou enunciados diversos, mas dado o feito do livro Toda Poesia, as declaraçóes que se multiplicaram pela mídia impressa e digital especializada dão conta de colocar a obra do poeta curitibano no campo do consumo.

Ao citar o nome de autor Leminski, o enunciador instaura um circuito cultural que circunscreve a poesia, a música, a ficção, o cinema em torno de uma produção contemporânea de cultura. O nome de autor Leminski é a garantia estabelecida pelo enunciador para propor uma "disputa" entre a produção contemporânea de poesia e a produção mercadológica. A novidade ou o espetacular se presentifica na possibilidade de que um circuito cultural contemporâneo seja puxado pela poesia, capaz de desestabilizar o capitalismo imediato, representado pela vendagem de best-sellers. Aliás, o que se presencia é a necessidade de se fazer uma arte consumível, se possível em massa e não apenas para fruição (FERREIRA \& NASCIMENTO, 2013).

Deste modo, ao desempenhar uma função mercadológica, a literatura de massa precisa de uma indústria alinhada às diversas redes de comunicação e informação, além de um conteúdo que satisfaça ao consumidor final. $\mathrm{Na}$ contramão dessa lógica, encontra-se a literatura pensada como patrimônio cultural, cuja valorização perpassa pelos aspectos éticos, estéticos e de linguagem e que, embora precise de uma rede de comunicação e informação para circular, não advém dela.

Nessa perspectiva, o campo do consumo, torna-se um lugar de embate. Neste lugar, a obra literária rivaliza entre si no que concerne à sua vendagem, como no supra referido verbete sobre obra-prima, esta é posta em relevo por sua comercialização. Logo, se as reflexôes acerca do lugar da leitura da obra literária não podem ter como fundamento apenas o conceito de obra literária, tampouco 
se alicerçar num leitor contemplativo ou numa crítica estética moderna, resta-nos discutirmos a ideia de um possível lugar no quadro das categorias constituídas nas discussóes sobre a ruptura da modernidade e pós-modernidade.

\section{Considerações finais}

A discussão sobre leitura de obras literárias e práticas de leitura na sociedade contemporânea requer algumas consideraçóes acerca das condiçóes sócio-históricas que essas práticas socioculturais estão sendo efetivadas. Se pensarmos em termos de crise, precisamos considerar a possibilidade de estarmos deslocando, sem nenhuma reformulação, categorias concebidas em outras condiçôes sócio-históricas. Talvez, possamos lembrar que o próprio estatuto da obra literária é não ter um lugar na sociedade que lhe torna possível.

Pensando em termos de transição, observamos que a contemporaneidade solicita novos modos de pensar e problematizar a leitura. Assim como as categorias de sujeito, de identidade, de tempo e espaço, história... foram deslocadas, as práticas socioculturais dos sujeitos, na contemporaneidade, sofreram mudanças. As questões referentes à cultura e à educação devem ser atualizadas de modo constante. O lugar da leitura de obra literária na contemporaneidade se apresenta como um lugar sempre em construção. Fica, aqui, a solicitação de possíveis diálogos sobre o tema.

\section{Referências}

ANDERSON, Perry. As origens da pós-modernidade. Trad. Marcus Penchel. Rio de Janeiro: Jorge Zahar, 1999.

ALVES, Susana. s.v. "obra”. E-Dicionário de Termos Literários (EDTL), coord. de Carlos Ceia, ISBN: 989-20-0088-9. Disponível em: <http://www.edtl. com.pt>, consultado em 3-out-2015.

BARRENTO, João. Que significa moderno? Interact. Revista Online de Arte, Cultura e Tecnologia, 2001. Disponível em http://www.interact.com.pt. Acesso em 1 abr. 2015.

BAUMAN, Zygmunt. O mal-estar na pós-modernidade. Rio de Janeiro: Jorge Zahar Ed., 1998.

. A modernidade líquida. Tradução Plínio Dentzien. Rio de Janeiro: Jorge Zahar, 2001. 
CHARTIER, Roger. Escutar os mortos com os olhos. Humanidades. Estudos Avançados 24(69), 2010. p. 7-30.

DEBORD, Guy. A sociedade do espetáculo. Versão para eBook, 2003. Disponível em: http://www.geocities.com/projetoperiferia. Acesso em: 5 de julho 2015.

EAGLETON, Terry. The Ilusions of postmodernism. Oxford, Inglaterra, 1996.

. Teoria da Literatura: uma introdução. Waltensir Dutra. 6a. ed. São Paulo: Martins Fontes, 2006.

FERREIRA, Anderson \& NASCIMENTO, Jarbas Vargas. Leminski, o Samurai: cenografia e ethos em web-manchetes In: SANTOS, Ivanaldo; NASCIMENTO, Maria Eliza Freitas; BARBOSA, Maria do Socorro Maia. (Orgs.). Análise do discurso: mídia, poder e heterogeneidade. João Pessoa: Marca de Fantasia, 2014, v. 1. p.341-369.

FREIRE, Paulo. Pedagogia do oprimido. 17a . ed. Rio de Janeiro: Paz e Terra, 1987.

- A importância do ato de ler: em três artigos que se completam. São Paulo: Autores Associados: Cortez, 1989.

. Pedagogia da autonomia: saberes necessários à prática educativa. São Paulo: Paz e Terra, 1996.

GIDDENS, Anthony. As consequências da modernidade. Tradução de Raul Fiker. São Paulo: Editora UNESP, 1991.

GRENZ, Stanley J. Pós-modernismo: um guia para entender a filosofia do nosso tempo. Editora Vida Nova, 2008.

HALL, Stuart. (1992) A identidade cultural na pós-modernidade. Rio de Janeiro: D P\&A, 2011.

INSTITUTO PRÓ-LIVRO. 3a. edição da pesquisa Retratos da Leitura no Brasil. http://prolivro.org.br/home/images/relatorios_boletins/3_ed_pesquisa_retratos_leitura_IPL.pdf, 20/07/2015.

JAMES, E. L. Cinquenta tons de Cinza. Rio de Janeiro: Editora Intrínseca, 2013.

JAMESON, Fredric. Pós-modernismo e a sociedade do consumo. Tradução Vinicius Dantas. Novos Estudos CEBRAP, São Paulo, no 12, p. 16-26. Jun. 1985.

LEMINSKI, Paulo. Toda poesia. São Paulo: Companhia da Letras, 2013.

LIPOVETSKY, Gilles \& CHARLES, Sébastien. Os Tempos Hipermodernos. São Paulo: Barcarolla, 2004. 
LYOTARD, Jean-François. La Condition postmoderne. Rapport sur le savoir, éditions de Minuit, 1979.

MAINGUENEAU, D. (1984) Gênese dos discursos. Trad. de Sírio Possenti. São Paulo: Parábola, 2008.

ODDONE, Nanci \& ROSA, Flávia Goullart Mota Garcia. Politicas públicas para o livro, leitura e biblioteca. Ci. Inf., Brasília, v. 35, n. 3, p. 183-193. Set. /dez. 2006.

PAULO LEMINSKI BATE CINQUENTA TONS DE CINZA EM LISTA DE MAIS VENDIDOS. http://ultimosegundo.ig.com.br, 5/8/2013.

REDESPTV. FLIP Antônio Candido. Disponível em www.youtube.com/ watch?v=z912yXNZY94, 20/09/2015.

SANTAELLA, Lúcia. Leitura fora do livro. http://ufba2011.com/A-LEITURA-FORA-DO-LIVRO.pdf,13/05/2015

SANTOS, Milton. Por uma outra globalização: do pensamento único à consciência universal. Rio de Janeiro: Editora Record, 2000.

SINOPSE. http://www.vidanova.com.br/produtos.asp?codigo=354, 25/7/2015.

\title{
POSTMODERNISM AND THE READING OF LITERARY WORKS
}

\begin{abstract}
In the light of the resulting discussions of Philosophy and Social theory about post modernity, this paper seeks to reflect, in a discursive perspective, about the place of reading literary works nowadays. It seeks to understand how social practices as reading books are transformed by the socio-historical conditions of the current historical period and the discursive practices about it.
\end{abstract}

KEYWORDS: Postmodernism, reading, literary works

Recebido em: 20/10/2015

Aprovado em: 15/03/2016 